\title{
Psilocybin-Induced Deficits in Automatic and Controlled Inhibition are Attenuated by Ketanserin in Healthy Human Volunteers
}

\author{
Boris B Quednow', Michael Kometer', Mark A Geyer² and Franz X Vollenweider*,I \\ 'Neuropsychopharmacology and Brain Imaging, Clinic of Affective Disorders and General Psychiatry, University Hospital of Psychiatry, \\ Heffter Research Center, Zürich, Switzerland; 'Department of Psychiatry, University of California at San Diego, La Jolla, CA, USA
}

\begin{abstract}
The serotonin-2A receptor $\left(5-\mathrm{HT}_{2 \mathrm{~A}} \mathrm{R}\right)$ has been implicated in the pathogenesis of schizophrenia and related inhibitory gating and behavioral inhibition deficits of schizophrenia patients. The hallucinogen psilocybin disrupts automatic forms of sensorimotor gating and response inhibition in humans, but it is unclear so far whether the 5-HT $2 A$ or $5-H T_{1 A} R$ agonist properties of its bioactive metabolite psilocin account for these effects. Thus, we investigated whether psilocybin-induced deficits in automatic and controlled inhibition in healthy humans could be attenuated by the $5-\mathrm{HT}_{2 \mathrm{~A} / 2 \mathrm{C}} \mathrm{R}$ antagonist ketanserin. A total of 16 healthy participants received placebo, ketanserin (40 mg p.o.), psilocybin (260 $\mathrm{gg} / \mathrm{kg}$ p.o.), or psilocybin plus ketanserin in a double-blind, randomized, and counterbalanced order. Sensorimotor gating was measured by prepulse inhibition (PPI) of the acoustic startle response. The effects on psychopathological core dimensions and behavioral inhibition were assessed by the altered states of consciousness questionnaire (5D-ASC), and the Color-Word Stroop Test. Psilocybin decreased PPI at short lead intervals (30 ms), increased all 5D-ASC scores, and selectively increased errors in the interference condition of the Stroop Test. Stroop interference and Stroop effect of the response latencies were increased under psilocybin as well. Psilocybin-induced alterations were attenuated by ketanserin pretreatment, whereas ketanserin alone had no significant effects. These findings suggest that the disrupting effects of psilocybin on automatic and controlled inhibition processes are attributable to $5-\mathrm{HT}_{2 \mathrm{~A}} \mathrm{R}$ stimulation. Sensorimotor gating and attentional control deficits of schizophrenia patients might be due to changes within the $5-\mathrm{HT}_{2 \mathrm{~A}} \mathrm{R}$ system.
\end{abstract}

Neuropsychopharmacology (2012) 37, 630-640; doi:10.1038/npp.20 I I.228; published online 28 September 20I I

Keywords: prepulse inhibition; sensorimotor gating; Stroop task; psilocybin; ketanserin; 5-HT2A receptor

\section{INTRODUCTION}

Automatic and controlled information-processing deficits, such as impairments in early and late inhibitory gating processes, are considered to constitute core symptoms of schizophrenia and appear to have a crucial role in the pathophysiology of schizophrenia (Braff et al, 2001; Geyer and Braff, 1987; McGhie and Chapman, 1961; Nuechterlein and Dawson, 1984; Nuechterlein et al, 1994; Venables, 1960). Although attentional and behavioral control processes have been linked to the serotonin system in general (Cools et al, 2008; Soubrié, 1986), early automatic inhibition of sensory stimuli (also called sensorimotor gating; Sipes and Geyer, 1997; Vollenweider et al, 2007) as well as controlled behavioral inhibition have been linked recently

*Correspondence: Dr FX Vollenweider, Neuropsychopharmacology and Brain Imaging, Clinic of Affective Disorders and General Psychiatry, University Hospital of Psychiatry, Heffter Research Center, Lenggstrasse 31, CH-8032 Zurich, Switzerland, Tel: +4I 443842404 , Fax: + 4I 44384 2249, E-mail: vollen@bli.uzh.ch

Received I July 20 I I; revised 3 August 20 I I; accepted 26 August 20 I I to the function of serotonin-2A receptors $\left(5-\mathrm{HT}_{2 \mathrm{~A}} \mathrm{Rs}\right)$ in particular (Robinson et al, 2008; Winstanley et al, 2004). Given the long-standing hypothesis that $5-\mathrm{HT}_{2 \mathrm{~A}} \mathrm{Rs}$ are implicated in the pathogenesis of schizophrenia (Dean, 2003; Geyer and Vollenweider, 2008; Meltzer, 1999; Meltzer et al, 2003; Quednow et al, 2010), 5- $\mathrm{HT}_{2 \mathrm{~A}} \mathrm{R}$ changes might also contribute to disturbed inhibitory processes seen in schizophrenia patients. Therefore, we investigated the role of $5-\mathrm{HT}_{2 \mathrm{~A}} \mathrm{Rs}$ in automatic and controlled inhibition processes in a model psychosis approach using the serotonergic hallucinogen psilocybin in healthy humans either pretreated with the $5-\mathrm{HT}_{2 \mathrm{~A} / 2 \mathrm{C}} \mathrm{R}$ antagonist ketanserin or placebo. Psilocybin (4-phosphoryloxy- $N, N$-dimethyltryptamine) is a prodrug that is rapidly metabolized into the bioactive main metabolite psilocin (4-hydroxy- $N, N$-dimethyltryptamine; Hasler et al, 1997, 2002) that acts as an agonist at $5-\mathrm{HT}_{1 \mathrm{~A}}, 5-\mathrm{HT}_{2 \mathrm{~A}}, 5-\mathrm{HT}_{2 \mathrm{~B}}, 5-\mathrm{HT}_{2 \mathrm{C}}$, and $5-\mathrm{HT}_{7} \mathrm{R}$ (Blair et al, 2000; Sard et al, 2005; Psychoactive Drug Screening Program (PDSP): http://pdsp.med.unc.edu). Ketanserin has about a 50 -fold greater antagonistic potency at $5-\mathrm{HT}_{2 \mathrm{~A}} \mathrm{R}$ than $5-\mathrm{HT}_{2 \mathrm{C}} \mathrm{R}$ and also some weak affinity at $5-\mathrm{HT}_{2 \mathrm{~B}}$ and $5-\mathrm{HT}_{7} \mathrm{R}$. Moreover, it is also strongly active at 
adrenergic $\alpha 1$ and histamine $\mathrm{H} 1$ receptors, and weakly active at some dopamine receptors (PDSP: http://pdsp. med.unc.edu). Given these activity profiles, it is conceivable that ketanserin blocks the activity of psilocin primarily at 5- $\mathrm{HT}_{2 \mathrm{~A} / 2 \mathrm{C}} \mathrm{Rs}$.

Prepulse inhibition (PPI) — which has been established as an operational measure of sensorimotor gating - is defined as a reduction of the startle reflex because of a weak sensory prestimulation (Braff et al, 1992; Graham, 1975). As patients with schizophrenia display impaired PPI (Braff et al, 1978, 1992; Kumari et al, 2000; Ludewig et al, 2003; Parwani et al, 2000; Quednow et al, 2006, 2008a; Swerdlow et al, 2006) drug-induced PPI deficits has become an important translational model of the gating impairment in schizophrenia.

Hallucinogenic 5- $\mathrm{HT}_{2 \mathrm{~A}} \mathrm{R}$ agonists such as LSD, 5-MeODMT, DOB, and DOI decrease PPI in rats (Johansson et al, 1995; Krebs-Thomson et al, 2006; Ouagazzal et al, 2001; Padich et al, 1996; Sipes and Geyer, 1995b, 1997). The PPIdisrupting effects of DOI and LSD are blocked by the selective $5-\mathrm{HT}_{2 \mathrm{~A}} \mathrm{R}$ antagonist MDL100, 907, which supports the hypothesis that the PPI-disrupting effects of these hallucinogens are mediated by $5-\mathrm{HT}_{2 \mathrm{~A}} \mathrm{Rs}$ (Halberstadt and Geyer, 2010; Ouagazzal et al, 2001; Padich et al, 1996; Sipes and Geyer, 1995b). However, a more recent study shows that the PPI-disrupting effects of 5-MeO-DMT could possibly be mediated by its agonistic effects at the $5-\mathrm{HT}_{1 \mathrm{~A}} \mathrm{R}$ because the PPI-disrupting effects were also abolished by WAY-100635 (Krebs-Thomson et al, 2006). Moreover, $5-\mathrm{HT}_{1 \mathrm{~A}} \mathrm{R}$ agonists such as 8-OH-DPAT or buspirone also diminish PPI in rats (Sipes and Geyer, 1995a; van den Buuse and Gogos, 2007) and humans (Gogos et al, 2006) but this effect seems to be limited to interstimulus intervals (ISIs) longer as $100 \mathrm{~ms}$. In humans, the hallucinogen psilocybin decreases and increases PPI at short $(<60 \mathrm{~ms})$ and long ISIs (>120 ms), respectively (Gouzoulis-Mayfrank et al, 1998; Vollenweider et al, 2007). Consequently, the question arose whether the PPI-disrupting effects of psilocybin in humans could be attributed to its $5-\mathrm{HT}_{2 \mathrm{~A}}$ or to its $5-\mathrm{HT}_{1 \mathrm{~A}}$ agonist properties. Additional evidence from human genetic studies suggests that polymorphisms of the $5-\mathrm{HT}_{2 \mathrm{~A}} \mathrm{R}$ (Quednow et al, 2008b, 2009), but not the $5-\mathrm{HT}_{1 \mathrm{~A}} \mathrm{R}$ (Brauer et al, 2009; Quednow, unpublished data), modulates PPI in humans.

The Color Word Stroop Interference Test is an established measure of response inhibition, attentional control, and cognitive flexibility (Barch et al, 2009; MacLeod, 1991; Spreen and Strauss, 1998), in which color words written in different ink colors are presented. Participants are told to name the ink color of the words but to ignore its denotation. If ink color and denotation are conflicting, an over-learned process of reading (semantic information) interferes with an intentional process of color naming (contextual information), resulting in increased reaction time (RT) and errors. Performance on this task is linked to the activation of the anterior cingulate cortex (ACC) and dorsolateral prefrontal cortex (DLPFC; Botvinick et al, 2004; Carter et al, 1998; Cohen et al, 2000; Mansouri et al, 2009; Pardo et al, 1990) - regions that are rich in 5- $\mathrm{HT}_{2 \mathrm{~A}} \mathrm{R}$ (Adams et al, 2004; Forutan et al, 2002; Pazos et al, 1987). In the classical card Stoop Test, schizophrenia patients consistently displayed increased susceptibility to interference effects in RT. In contrast, on trial-by-trial versions of the task, normal RT interference but increased RT facilitation (RT enhancement in congruent trials) and increased error rates and RT in the conflicting trials have been demonstrated (for review see Henik and Salo, 2004). Neuroimaging studies suggested a conflict-related hypoactivation of the ACC during Stroop interference in schizophrenia patients (Melcher et al, 2008). Recently, it was shown that sensorimotor gating and performance in the Stroop task are correlated indicating that they may be mediated by common attentional or inhibitory processes (Scholes and Martin-Iverson, 2009).

Acute tryptophan depletion, which transiently depletes brain 5-HT, has been reported to decrease RT interference in the Stroop Test in some (Evers et al, 2006; Schmitt et al, 2000; Scholes et al, 2007) but not all studies (Gallagher et al, 2003; Horacek et al, 2005; Sobczak et al, 2002). Moreover, acute 5-HT release induced by dexfenfluramine or MDMA also did not alter Stroop Test performance (Andrews and Anderson, 1998; Vollenweider et al, 1998a). More specifically, early studies found that the preferential $5-\mathrm{HT}_{2 \mathrm{~A}} \mathrm{R}$ agonist LSD impaired performance in the Stroop Test in healthy controls as well as in schizophrenia patients (Krus et al, 1963; Wapner and Krus, 1960). Recent evidence suggests that the $5-\mathrm{HT}_{2 \mathrm{~A} / 1 \mathrm{~A}} \mathrm{R}$ agonist psilocybin and the $5-\mathrm{HT}_{2 \mathrm{~A} / 2 \mathrm{C}} \mathrm{R}$ agonist DMT disrupted a similar inhibitory mechanism of attention as measured with the inhibition-ofreturn (IOR) task, in which performance has been shown to be disturbed in schizophrenia (Daumann et al, 2008; Gouzoulis-Mayfrank et al, 2002, 2004, 2006a, b, 2007). Finally, cyproheptadine - an antagonist at $5-\mathrm{HT}_{2 \mathrm{~A} / 2 \mathrm{~B} / 2 \mathrm{C}}, 5-$ $\mathrm{HT}_{1 \mathrm{~A}}$, and $5-\mathrm{HT}_{7} \mathrm{R}$ with high affinity also for histamine and muscarinic receptors (PDSP: http://www.pdsp.med.unc. edu) -improves RT in the conflict condition of the Stroop Test in chronic schizophrenia patients (Chaudhry et al, 2002), whereas the partial $5-\mathrm{HT}_{1 \mathrm{~A}} \mathrm{R}$ agonist buspirone had no effect on Stroop performance in schizophrenia patients (Piskulic et al, 2009). Taken together, these results imply that $5-\mathrm{HT}_{2 \mathrm{~A}} \mathrm{Rs}$ are probably involved in controlled inhibitory mechanisms that are needed to accomplish tasks such as the Stroop Test.

Hence, we further investigated the role of the $5-\mathrm{HT}_{2 \mathrm{~A}} \mathrm{R}$ in the modulation of automatic (sensorimotor gating) and controlled (Stroop interference) inhibition processes in healthy human volunteers with a placebo-controlled, crossed, counterbalanced, and double-blind design. We examined whether a pretreatment with the $5-\mathrm{HT}_{2 \mathrm{~A} / 2 \mathrm{C}} \mathrm{R}$ antagonist ketanserin could prevent the inhibition-disrupting effects of psilocybin. Owing to previous studies, we expected that ketanserin pretreatment would reduce psilocybin-induced disruptions of PPI and Stroop interference, while preventing formation of an altered state of consciousness (ASC).

\section{MATERIALS AND METHODS}

\section{Participants}

A total of 16 healthy subjects (13 males, 3 females; mean age: 29.7 years, age range: $24-39$, all were students or academics) were recruited through advertisement from the local universities. Subjects were healthy according to medical history, clinical examination, electrocardiography, and blood analysis. Subjects were screened by the DIA-X 
diagnostic expert system (Wittchen and Pfister, 1997), a semi-structured psychiatric interview to exclude those with personal or family (first-degree relatives) histories of major psychiatric disorders, and standard psychometric instruments including the Freiburg Personality Inventory (FPI; Fahrenberg et al, 1984), the State Trait Anxiety Inventory STAI (Spielberger et al, 1970), and the Symptom Checklist SCL-90R (Derogatis, 1994). As the personality trait factors rigidity and emotional lability predict negative experiences under hallucinogens (Dittrich, 1994), scores two SD above the mean value of normative data in the respective subscales of the FPI (ie, openness and neuroticism) were exclusion criteria. No subject had to be excluded using these criteria. Five of the subjects were occasional smokers, seven subjects reported a sporadic or rare cannabis use in the past ( $<5$ joints/month), one subject had prior experiences with MDMA (two pills lifetime), and two subjects reported experiences with psilocybin (one and two occasions lifetime).

This study was approved by the Ethics Committee of the University Hospital of Psychiatry, Zurich; the use of psilocybin was authorized by the Swiss Federal Office for Public Health, Department of Pharmacology and Narcotics, Bern. All volunteers gave their written consent after being informed by written and oral descriptions of the study and their risks.

\section{Psilocybin}

Psilocybin was obtained through the Swiss Federal Office of Public Health, Department of Pharmacology and Narcotics, Berne and prepared as capsules of $1 \mathrm{mg}$ and $5 \mathrm{mg}$ at the Pharmacy of the Cantonal Hospital of Aarau, Switzerland. Psilocybin, ketanserin, and lactose placebo were administered in gelatin capsules of identical appearance.

\section{Study Design}

The study was double-blind and placebo-controlled, and included four experimental days. All subjects received placebo, a variable dose of psilocybin $(260 \mu \mathrm{g} / \mathrm{kg})$, a fixed dose of ketanserin ( $40 \mathrm{mg}$, Suffrexal), and a combination of both drugs p.o. each on single test days separated by 4 -week intervals and in a randomized and counterbalanced order. Because of variations of PPI with menstrual cycle, women were tested in the first 5 days of their follicular phase when PPI is most robust (Swerdlow et al, 1997). The five occasional smokers were told to maintain their usual smoking habits to ensure that PPI was not influenced by smoking withdrawal (Kumari and Gray, 1999).

Sessions were conducted in a calm and comfortable laboratory environment. Participants were told to abstain from alcohol the day before each session and not to drink caffeine-containing beverages or to eat $2 \mathrm{~h}$ before each session. One hour after arrival, subjects received placebo/ ketanserin in capsules (0900 hours) and after another $40 \mathrm{~min}$ placebo/psilocybin. Startle measures were obtained $60 \mathrm{~min}$ after placebo/psilocybin intake. The Stroop task was conducted $85 \mathrm{~min}$ after treatment, while the 5D-ASC rating was conducted about $125 \mathrm{~min}$ after treatment. Both measures were assessed during the known plateau of about $50 \mathrm{~min}$ of psilocybin response. The peak of the subjective hallucinogenic effects occurs after $70-90 \mathrm{~min}$, while the psilocin plasma peak is reached after $105 \mathrm{~min}\left(t_{\max }\right)$ with a half-life $\left(t_{1 / 2}\right)$ of $163 \mathrm{~min}$ (Hasler et al, 1997, 2002; Passie et al, 2002). An oral dose of $40 \mathrm{mg}$ ketanserin shows a $t_{\max }=65 \mathrm{~min}$ and a half-life of $t_{1 / 2}=29.2 \mathrm{~h}$ (Persson et al, 1987). After the acute effects of psilocybin had subsided completely (about $360 \mathrm{~min}$ after treatment), subjects remained in the hospital for another $2 \mathrm{~h}$ and were monitored clinically.

\section{Startle Response Measurement}

PPI was recorded and analyzed as described in detail previously (Vollenweider et al, 1999; Vollenweider et al, 2007). In brief, each session began with a 5-min acclimation period of $70-\mathrm{dB}$ background white noise that continued throughout the session consisting of a total of 52 trials presented in a pseudorandom order and separated by intertrial intervals varying between 4 and $22 \mathrm{~s}$ (mean $13 \mathrm{~s}$ ). The session started and ended each with five $115-\mathrm{dB}$ pulse-alone (PA) trials (white noise) of $40 \mathrm{~ms}$ duration that were not used for the calculation of PPI. The trials in between these two blocks consisted of three conditions: 12 PA trials; 24 prepulse-pulse (PP) trials consisting of a $20-\mathrm{ms}$ duration prepulse of either $78 \mathrm{~dB}$ or $86 \mathrm{~dB}$ white noise presented with an ISI of 30 or $120 \mathrm{~ms}$ before the PA, yielding four types of PP trials $\left(30 \mathrm{~ms} \_78 \mathrm{~dB}, 30 \mathrm{~ms} \_86 \mathrm{~dB}, 120 \mathrm{~ms} \_78 \mathrm{~dB}\right.$, $120 \mathrm{~ms} \_86 \mathrm{~dB}$, six of each type); and 6 no-stimulus trials. The intensity conditions $(78 \mathrm{~dB}$ or $86 \mathrm{~dB}$ ) were pooled for further analysis. The entire test session took about $15 \mathrm{~min}$.

Error trials were defined as trials in which no startle response was recorded because of a baseline shift (eg, due to spontaneous or voluntary blinks). Subjects with error trials and/or response rejections $>50 \%$ were excluded from data analysis. None the 16 subjects participating in the study had to be excluded from data analysis based on this criterion. As detailed elsewhere (Ludewig et al, 2003), the startle measures examined were: (1) startle reactivity $=$ mean amplitude of all PA trials; (2) \%habituation $=(1-$ (startle amplitude of 1 . PA block/startle amplitude of last PA block) $\times 100$; and (3) $\% \mathrm{PPI}=$ according to the formula (1-(mean startle amplitude of PP trials/mean startle amplitude of PA trials in the middle block) $\times 100$ ).

\section{The Altered State of Consciousness Rating Scale}

The 5D-ASC rating scale (Dittrich et al, 1985; Dittrich, 1998) was used to assess the subjective effects of drug conditions and has been described in detail elsewhere (Vollenweider et al, 2007). The 5D-ASC questionnaire is a visual-analogue scale consisting of 94 items assessing three key dimensions of ASC: (1) oceanic boundlessness (OB), (2) anxious ego dissolution (AED), and (3) visionary restructuralization (VR). The subscales of the key dimensions have been described previously (Vollenweider et al, 2007).

\section{Stroop Task}

A computerized version of the trial-by-trial Color Word Stroop Test was used, as described in detail previously (Vollenweider et al, 1998a). Stimuli were presented using MEL Professional 2.0 software (PST Pittsburgh, PA, USA) 
and an IBM-compatible PC with a VGA color monitor. The latencies of subjects' spoken responses were collected with millisecond accuracy through a microphone (Labtec AM22). The stimulus set consisted of the German words OBEN (above), UND (and), WENN (if), KAUM (hardly), BLAU (blue), GRÜN (green), ROT (red), GELB (yellow), and the non-word XXXX presented in the colors blue, red, green, or yellow. Four conditions, corresponding to four types of trials, were included: On congruent trials, words matched colors (eg, the word BLAU written in blue); on conflict trials, words mismatched colors (eg, BLAU written in red); on neutral X trials, the non-word sequence XXXX was presented in one of the four colors; and on neutral $\mathrm{W}$ trials, one of the neutral words (OBEN, UND, WENN, KAUM) was presented in one of the four colors (Carter et al, 1995). Forty-eight trials of each condition were presented in random order to minimize strategy effects yielding a total of 192 trials. The task was to name the colors of the stimuli as quickly and accurately as possible. Before each stimulus, a fixation cross appeared in the center of the screen for $400 \mathrm{~ms}$ followed by the stimulus itself, which remained on the screen until the subject made a verbal response. Completion of the entire task took $10 \mathrm{~min}$.

Facilitation was defined as absolute reduction in $\mathrm{RT}$ in the congruent condition compared with the pooled X and $\mathrm{W}$ condition (mean congruent RT-mean (X+W/2) RT). Interference was defined as the absolute increase in RT in the conflict condition compared with the pooled $\mathrm{X}$ and $\mathrm{W}$ condition (mean conflict RT-mean $(\mathrm{X}+\mathrm{W} / 2) \mathrm{RT}$ ). The total Stroop effect was defined as absolute increase of RT in the conflict condition compared with congruent condition (mean conflict RT - mean congruent RT).

\section{Statistical Analysis}

All data were analyzed using STATISTICA 7.1. for Windows (StatSoft). Startle and PPI data were analyzed using repeated measures analyses of variance (ANOVA) with drug (placebo, psilocybin, ketanserin, psilocybin + ketanserin), $\mathrm{PP}$ intensity $(78 \mathrm{~dB}, 86 \mathrm{~dB})$, and ISI $(30 \mathrm{~ms}, 120 \mathrm{~ms})$ as within-subject factors. An ANOVA with the repeated measurement factors drug and Stroop condition (word, XXXX, incongruent, congruent) was used to test for significant effects of psilocybin on the Stroop task, while a repeated measurement ANOVA with 5D-ASC dimensions and drug as within-subject factors were used to examine the effect on the 5D-ASC scale. Based on significant main effects or interactions, Tukey's post-hoc comparisons were performed. With exception of the 5D-ASC scores under placebo, all dependent variables were normally distributed. Pearson's product moment correlations were conducted to explore the relationship between \%PPI and Stroop task. The criterion for significance was set at $p<0.05$.

\section{RESULTS}

\section{Psychological Effects of Psilocybin}

As previously reported (Hasler et al, 2009; Kometer et al, 2011; Vollenweider et al, 2007), psilocybin produced an altered state that was characterized by derealization and depersonalization phenomena, affective changes, thought

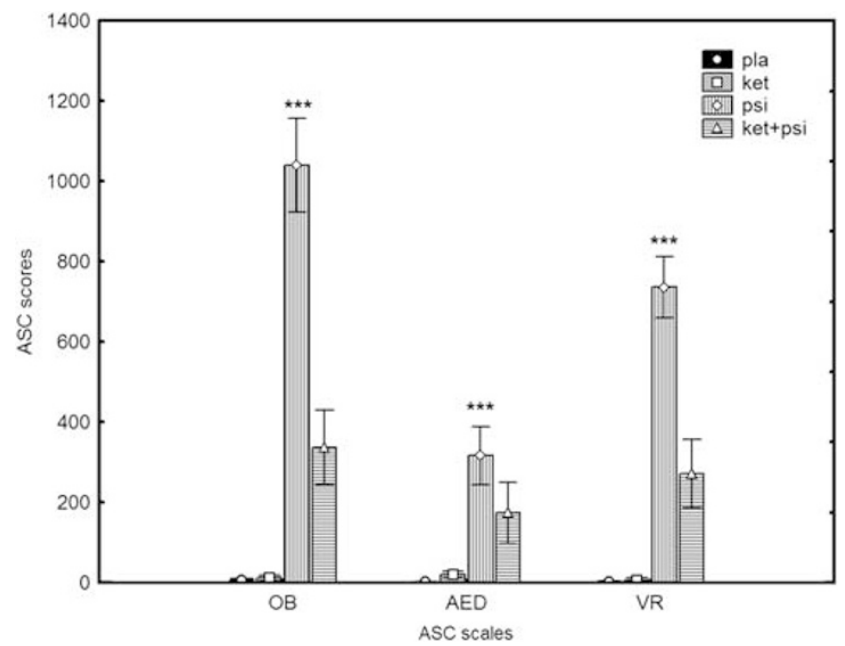

Figure I Effects of placebo, ketanserin (40 mg), psilocybin $(260 \mu \mathrm{g} / \mathrm{kg})$, and psilocybin in combination with a pretreatment of ketanserin on the 5D-ASC (altered states of consciousness) in healthy human volunteers. Significant changes compared with placebo are indicted by ***** $P_{\text {Tukey post hoc }}=0.00 \mathrm{I}$. Mean scores $\pm \operatorname{SEM}(n=16)$. AED, anxious ego dissolution; ASC, altered state of consciousness; OB, oceanic boundlessness; VR, visionary restructuralization.

disorder, and perceptual alterations. Psilocybin was well tolerated physically and mentally by all subjects, with none of our subjects reporting persisting residual psychotropic effects in systematic follow-up investigations (Studerus et al, 2011).

A 2-way ANOVA (drug $* 5 \mathrm{D}$-ASC dimension) revealed that psilocybin produced significant psychotomimetic effects on all scales (main effect of drug: $\mathrm{F}(3,45)=48.3, p<0.0001$; post-hoc tests psilocybin $v$ s placebo, all $p<0.0002$; Figure 1). There was a significant interaction of drug $* 5 \mathrm{D}$-ASC dimension because the psilocybin effect was most pronounced on the $\mathrm{OB}$ scale $(\mathrm{F}(6,90)=17.2, p<0.0001)$. Ketanserin alone did not induce any symptoms, but significantly reduced the psychotomimetic effects of psilocybin on $\mathrm{OB}$ and VR scales (psilocybin $v s$ ketanserin plus psilocybin: both $p<0.0002$ ), while the reduction in AED was visible but not significant. However, further inspection of the AED subscale scores revealed that ketanserin significantly reduced the psilocybin-induced elevation specifically in the subscales thought disorder $(p<0.00005)$ and fear of losing control over thinking $(p<0.02)$.

\section{Effect of Psilocybin and Ketanserin on Startle Amplitude and Habituation}

As shown in Figure 2, a 2-way ANOVA (block $\star$ drug) revealed significant effects of the factors block $(\mathrm{F}(2,30)=79.2, \quad p<0.0001)$ and $\operatorname{drug}(\mathrm{F}(3,45)=8.13$, $p=0.0002)$. Post-hoc testing showed that psilocybin alone (NS) did not affect startle response, whereas ketanserin $(p<0.0015)$ and ketanserin plus psilocybin $(p<0.015)$ significantly reduced startle reactivity. The lack of a significant drug $*$ block interaction $(F(6,90)<1$, NS) indicates no differences in habituation between drug conditions. 


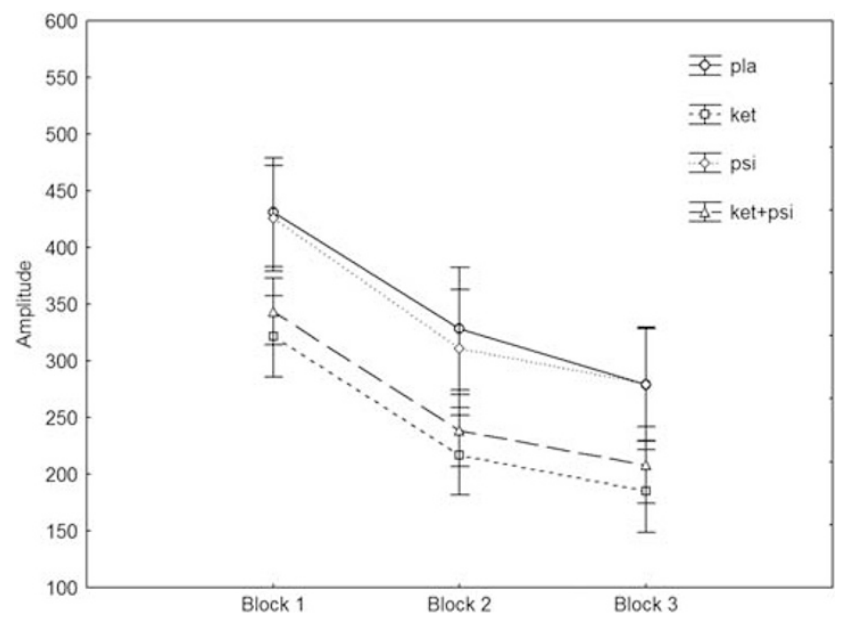

Figure 2 Effects of placebo, ketanserin $(40 \mathrm{mg})$, psilocybin $(260 \mu \mathrm{g} / \mathrm{kg})$, and psilocybin in combination with a pretreatment of ketanserin on startle amplitude and habituation across three blocks of pulse-alone trials in healthy human volunteers. Mean scores $\pm \operatorname{SEM}(n=16)$.

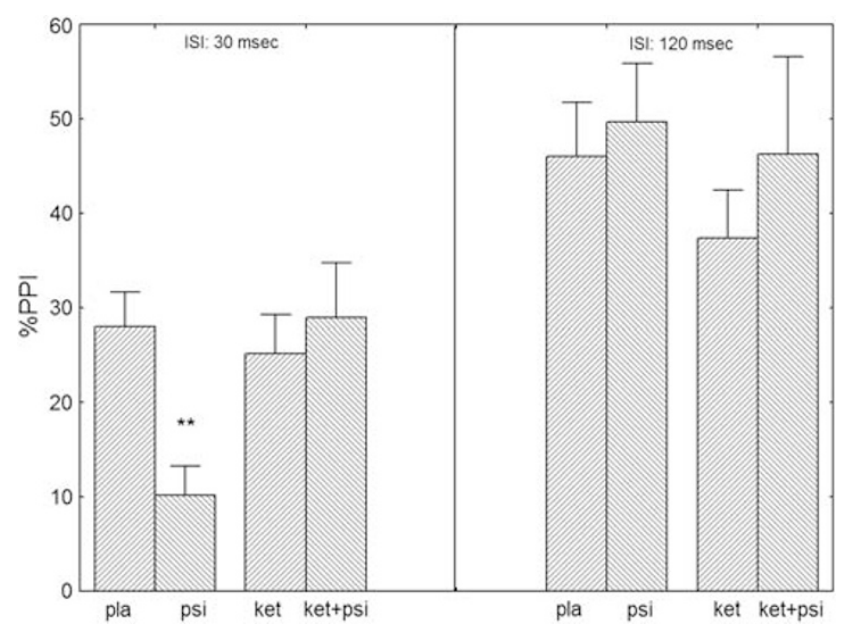

Figure 3 Effects of placebo, ketanserin $(40 \mathrm{mg})$, psilocybin $(260 \mu \mathrm{g} / \mathrm{kg})$, and psilocybin in combination with a pretreatment of ketanserin on prepulse inhibition (PPI) of the acoustic startle response in healthy human volunteers. Significant differences compared with placebo are indicated by $* * P_{\text {Tukey post hoc }}=0.0 \mathrm{I}$. Mean scores \pm SEM (pooled prepulse intensities, $n=16$ ). ISI, interstimulus-interval; ket, ketanserin; ket + psi, ketanserin + psilocybin; pla, placebo; psi, psilocybin.

\section{Effect of Psilocybin and Ketanserin on Percent PPI}

An initial 4-way ANOVA (pretreatment $*$ treatment $*$ intensity $*$ ISI) revealed an interaction of pretreatment $*$ treatment and ISI $(F(1,15)=4.21, p<0.05)$ reflecting differential effects of the drugs on ISI conditions (Figure 3). Post-hoc tests showed that psilocybin decreased \%PPI in the $30 \mathrm{~ms}$ condition $(p<0.008)$ and that this effect was reversed by ketanserin (NS). At the long ISI of $120 \mathrm{~ms}$, psilocybin slightly increased \%PPI, whereas ketanserin slightly decreased \%PPI, but these effects were not significant. As expected the factors intensity $(\mathrm{F}(1,15)=43.4, p<0.0001)$ and ISI $(\mathrm{F}(1,15)=36.7, p<0.0001)$ were significant. Introduction of smoking status as a covariate did not affect these results.

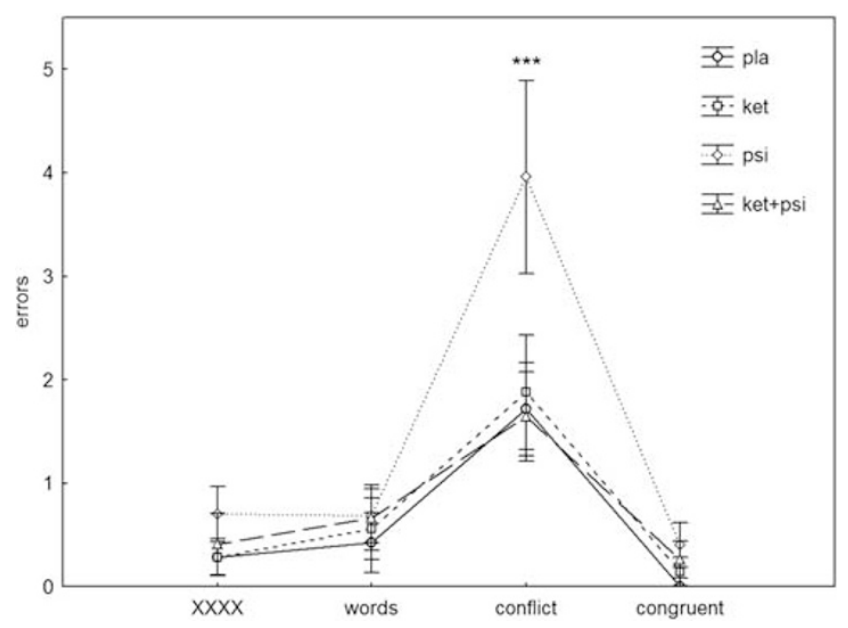

Figure 4 Effects of placebo, ketanserin (40 mg), psilocybin $(260 \mu \mathrm{g} / \mathrm{kg})$, and psilocybin in combination with a pretreatment of ketanserin on errors in the Stroop Test in healthy human volunteers. Mean scores \pm SEM $(n=16)$. Significant changes compared with placebo are indicted by **** $P_{\text {Tukey post hoc }}=0.00 \mathrm{I}$. XXXX represents a non-word sequence.

\section{Effect of Psilocybin on Stroop Test}

A 2-way ANOVA (drug*Stroop condition) of the errors showed significant effects of drug $(\mathrm{F}(3,45)=6.26$, $p<0.001)$, condition $(\mathrm{F}(3,45)=17.9, p<0.0001)$, and their interaction $(\mathrm{F}(9,135)=2.39, p<0.015)$. In post-hoc tests, psilocybin increased error rates in the conflict condition $(p<0.0001)$, which was reversed by ketanserin $(p<0.0001)$. Ketanserin alone did not alter Stroop error rates (NS; Figure 4).

A similar analysis of the RT showed significant effects of drug $(\mathrm{F}(3,45)=9.51, p<0.0001)$, condition $(\mathrm{F}(3,45)=$ $61.6, p<0.00001)$, and their interaction $(\mathrm{F}(9,135)=3.62$, $p<0.0005)$. In contrast to the errors, psilocybin increased RT in all conditions (all $p<0.00003$ ), which was substantially reduced by ketanserin (all $p<0.00003$ ). Again, ketanserin alone did not alter RT (Figure 5).

As shown in Table 1, psilocybin significantly increased Stroop interference and Stroop effect compared with placebo and ketanserin. This effect was neutralized by the combination of psilocybin and ketanserin. Psilocybin alone did not change facilitation but in combination with ketanserin facilitation was enhanced. Ketanserin alone did not alter interference, Stroop effect, or facilitation.

\section{Relationships between PPI, Stroop Test, and Altered States of Consciousness}

To explore the relationship between PPI and clinical symptoms in psilocybin states, data obtained during the peak effects of psilocybin and psilocybin plus ketanserin were pooled $(n=32)$, and correlation analyses between PPI change scores (psilocybin-placebo and of psilocybin/ ketanserin - placebo) and the 5D-ASC scale change scores or Stroop measures were performed. The change in PPI obtained at the $30 \mathrm{~ms}$ lead interval correlated significantly with $\mathrm{OB}(R=0.47, p<0.01)$ and VR scores $(R=0.40$, $p<0.05$ ), but not with any change scores of the Stroop task performance. In other words, the higher the reduction in 
\%PPI in psilocybin or psilocybin plus ketanserin condition, the more OB or VR symptoms occurred. Subsequent analyses of the $\mathrm{OB}$ and VR subscale scores revealed that these correlations were driven by derealization phenomena, mania-like symptoms and changed meaning in percepts (data not shown). However, a similar analysis of the pooled 5D-ASC change scores and the Stroop RT revealed that the change in AED score correlated significantly with the Stoop interference obtained in the neutral X $(R=0.40, p<0.05)$ and $\mathrm{W}$ condition $(R=0.35, p<0.05)$. Analyses of the AED subscale scores showed that this correlation was driven by thought disorder and loss of control over thinking and body (data not shown).

\section{DISCUSSION}

The present study demonstrated that the $5-\mathrm{HT}_{2 \mathrm{~A} / 2 \mathrm{C}} \mathrm{R}$ antagonist ketanserin abolished the disrupting effects of

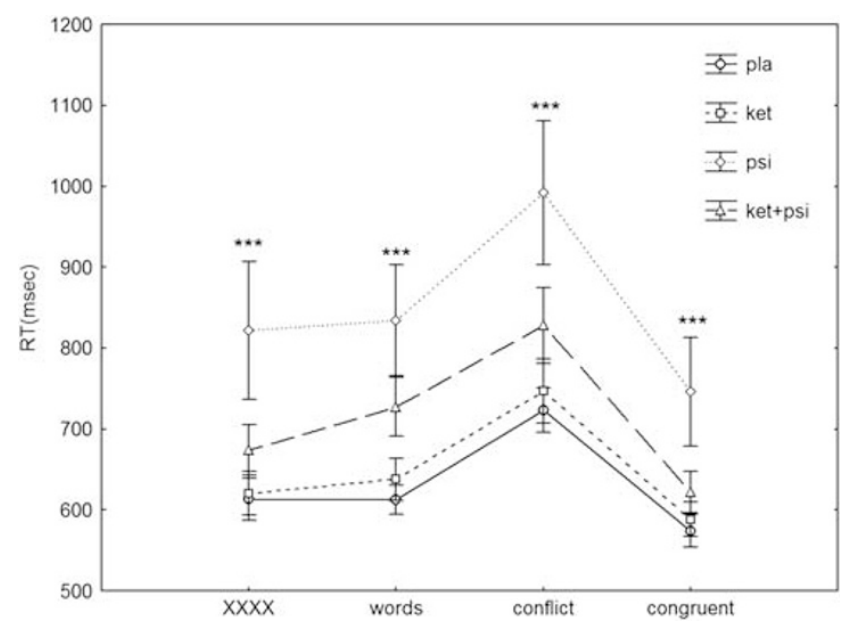

Figure 5 Effects of placebo, ketanserin (40 mg), psilocybin $(260 \mu \mathrm{g} / \mathrm{kg})$, and psilocybin in combination with a pretreatment of ketanserin on response time (RT) in the Stroop Test in healthy human volunteers. Mean scores \pm SEM $(n=16)$. Significant changes compared with placebo are indicted by ${ }^{* * * *} P_{\text {Tukey post hoc }}=0.001$. $X X X X$ represents a non-word sequence. the $5-\mathrm{HT}_{2 \mathrm{~A} / 2 \mathrm{~B} / 2 \mathrm{C} / 1 \mathrm{~A}} \mathrm{R}$ agonist psilocybin on automatic (sensorimotor gating) and controlled (Stroop interference) inhibition processes. Moreover, we again replicated our previous findings that most of the subjective hallucinogenic effects of psilocybin are substantially neutralized by ketanserin (Carter et al, 2005, 2007; Vollenweider et al, 1998b).

In a previous study, we found that psilocybin reduced PPI at short $(30 \mathrm{~ms})$, had no effect at medium $(60 \mathrm{~ms})$, and increased PPI at long (120 and $240 \mathrm{~ms}$ ) ISIs (Vollenweider et al, 2007). We found a similar pattern in the present study, although the increase of PPI in the $120 \mathrm{~ms}$ ISI condition was not significant. The lacking significance regarding the increase at $120 \mathrm{~ms}$ might be due to the fact that a somewhat higher dose of psilocybin was used in the present study $(260 \mu \mathrm{g} / \mathrm{kg})$ compared with the dose with which we found the significant effect in our previous study $(215 \mu \mathrm{g} / \mathrm{kg})$, and that the response in the 120 ISI condition appears to follow an inverse-U relationship (no significant increase at $315 \mu \mathrm{g} /$ $\mathrm{kg}$, Vollenweider et al, 2007). Moreover, indirect stimulation of all 5-HT receptors by SSRI has also shown no effect on PPI at 60 and $120 \mathrm{~ms}$ ISIs in previous studies (Jensen et al, 2007; Oranje et al, 2011; Quednow et al, 2004), which is in line with our present results. We previously hypothesized that the reduction of PPI at short ISIs is caused by the $5-\mathrm{HT}_{2 \mathrm{~A}} \mathrm{R}$ agonist action of psilocybin, whereas the increase at long ISIs might be due to its 5$\mathrm{HT}_{1 \mathrm{~A}} \mathrm{R}$ agonist action (Vollenweider et al, 2007). The present results strongly suggest that the psilocybin-induced PPI disruption at short ISIs is generated by the action of psilocybin at $5-\mathrm{HT}_{2 \mathrm{~A}} \mathrm{Rs}$. This finding further supports the assumption that PPI deficits in schizophrenia might be induced by $5-\mathrm{HT}_{2 \mathrm{~A}} \mathrm{R}$ changes (Quednow et al, 2008b, 2009). Moreover, as demonstrated in two previous studies, psilocybin again showed no significant effect on startle reactivity or habituation (Gouzoulis-Mayfrank et al, 1998; Vollenweider et al, 2007).

Furthermore, we found a slight and non-significant reduction of startle reactivity by ketanserin, which is partly in line with a previous study reporting that the same dose of ketanserin $(40 \mathrm{mg})$ significantly reduced startle amplitude (Graham et al, 2002). In contrast, Graham et al (2002) also described that ketanserin disrupts PPI-a finding that we

Table I Performance in the Stroop Test under Placebo, Ketanserin, Psilocybin, and Psilocybin + Ketanserin ( $n=16$, Mean and Standard Error of Means of Change in Response Time (RT) in millisecond are Shown)

\begin{tabular}{|c|c|c|c|c|c|c|c|}
\hline Condition & Placebo & Ketanserin & Psilocybin & Psilocybin+Ketanserin & $\mathbf{F}$ & df & $p$ \\
\hline \multicolumn{8}{|l|}{ Interference } \\
\hline (Conflict RT - pooled XXXX and word RT) & | 10.1 ( $(19.3)$ & $118.0^{\circ}(24.3)$ & 188.7* (52.8) & $127.3(23.6)$ & 4.04 & 3,45 & 0.01 \\
\hline \multicolumn{8}{|l|}{ Facilitation } \\
\hline (Congruent RT - pooled $X X X X$ and word RT) & $-35.5(16.2)$ & $-63.4(26.5)$ & $-43.8(9.7)$ & $-96.7^{* * *}(25.9)$ & 5.50 & 3,45 & 0.003 \\
\hline \multicolumn{8}{|l|}{ Stroop } \\
\hline (Conflict RT - congruent RT) & | $48.7(\mid 4.6)$ & $158.6^{\circ 00}(22.6)$ & $245.4 * * * * *(35.6)$ & $205.7(23.5)$ & 8.29 & 3,45 & 0.0002 \\
\hline
\end{tabular}

Tukey's HSD post-hoc test vs placebo: *p $<.05$, *** $<.01$, **** $<.001$

Tukey's HSD post-hoc test vs psilocybin: ${ }^{\circ} \mathrm{p}<.05,{ }^{\circ 00} \mathrm{p}<.001$. 
could not replicate. However, the PPI-disrupting effects reported by Graham et al (2002) might be the result of the strong reduction in startle amplitude found in their experiment (Csomor et al, 2008). Although, Graham's and our experimental setups were similar, the different results may have been because of some specific parametric differences in prepulse durations, trial sequences, and the lack of startle-alone trials before assessing PPI. Furthermore, it appears unlikely that an effect of ketanserin on startle amplitude influenced our main findings because the inclusion of startle amplitude as a covariate did not change our results.

Our results are partly in line with the finding that selective $5-\mathrm{HT}_{1 \mathrm{~A}} \mathrm{R}$ agonists decrease PPI only at ISIs $>100 \mathrm{~ms}$ (Gogos et al, 2006; van den Buuse and Gogos, 2007). However, the psilocybin-induced increase of PPI at $120 \mathrm{~ms}$ seen in the present and our previous experiment (Vollenweider et al, 2007) seems not to be caused by the $5-\mathrm{HT}_{1 \mathrm{~A}} \mathrm{R}$ agonistic properties of the compound. This effect might be induced by an interaction between the $5-\mathrm{HT}_{1 \mathrm{~A}}, 5-\mathrm{HT}_{2 \mathrm{~A}}$, or $5-\mathrm{HT}_{2 \mathrm{C}} \mathrm{R}$ because ketanserin did not block the small PPI enhancing effect of psilocybin at $120 \mathrm{~ms}$. To investigate the contribution of $5-\mathrm{HT}_{1 \mathrm{~A}}, 5-\mathrm{HT}_{2 \mathrm{~A}}$, and $\mathrm{HT}_{2 \mathrm{C}} \mathrm{Rs}$ on the PPI-changing effects of psilocybin, further studies should incorporate a blockade of these receptor types in combination with a variety of short and long ISI ranging from $30-240 \mathrm{~ms}$.

Psilocybin significantly increased RT and error rates particularly in the conflict condition of a computerized trial-by-trial Stroop Test, a pattern of results that is similar to that reported for schizophrenia patients (Henik and Salo, 2004). Ketanserin prevented these deficits in the conflict condition, suggesting that the $5-\mathrm{HT}_{2 \mathrm{~A}} \mathrm{R}$ agonist action of psilocybin disturbed processes that influence performance in the conflict condition of the Stroop Test. Performance in the Stroop Test is based upon mechanisms that involve the active selection and maintenance of an appropriate task rule, including working memory, attentional control, conflict monitoring, and inhibition processes (Barch et al, 2009). We have previously demonstrated that psilocybin impairs attentional processes (Carter et al, 2005; Vollenweider et al, 2007), while working memory is less affected (Carter et al, 2005; Wittmann et al, 2007). Furthermore, the psilocybin-induced disturbance of attentional tracking ability could not be blocked by ketanserin, suggesting a primary involvement of $5-\mathrm{HT}_{1 \mathrm{~A}} \mathrm{R}$ in this effect (Carter et al, 2005). In addition, it was shown that psilocybin also impairs performance in the IOR Task, which is supposed to reflect an automatic inhibitory mechanism of attention (Gouzoulis-Mayfrank et al, 2002). Taken together, these findings suggest that the effect of psilocybin on the performance in the conflict condition of the Stroop Test might rather be explained by a dysfunction of conflict monitoring and/or inhibition processes than by an effect on working memory or attention per se.

The different interactions of psilocybin and ketanserin on various cognitive functions might be explained by the fact that immunohistochemical studies have demonstrated that $5-\mathrm{HT}_{1 \mathrm{~A}} \mathrm{Rs}$ are colocalized with $5-\mathrm{HT}_{2 \mathrm{~A}} \mathrm{Rs}$ receptors in cortical pyramidal cells (Martin-Ruiz et al, 2001), where both receptor subtypes displayed opposing effects when they were stimulated (Araneda and Andrade, 1991).
Specifically, studies in rats have shown that $5-\mathrm{HT}_{1 \mathrm{~A}}$ and 5 $\mathrm{HT}_{2 \mathrm{~A}} \mathrm{Rs}$ in the medial prefrontal cortex (mPFC) exert opposite action on attentional functioning and aspects of executive functioning (Carli et al, 2006). Thus, the results of Carter et al (2005) are not necessarily in conflict with the present findings.

Our data are consistent with two early studies showing that performance on the classical card version of the Stroop Test is disrupted by the $5-\mathrm{HT}_{2 \mathrm{~A} / 2 \mathrm{~B} / 2 \mathrm{C}}, 5-\mathrm{HT}_{1 \mathrm{~A} / 1 \mathrm{~B} / 1 \mathrm{D}}$, and $5-$ $\mathrm{HT}_{6 / 7} \mathrm{R}$ agonist LSD. However, LSD also affected the performance in the congruent conditions (cards A and B), even though the effect was most pronounced in the conflict condition (card C; Krus et al, 1963; Wapner and Krus, 1960). That the 5-HT system is crucially involved in processes involved in the performance of the Stroop Test has been shown by several studies: (1) acute tryptophan depletion reduces RT interference in the Stroop Test (Evers et al, 2006; Schmitt et al, 2000; Scholes et al, 2007); (2) performance in the conflict condition of the Eriksen Flanker Task (Reuter et al, 2007) as well as in congruent conditions of the Stroop Test (Osinsky et al, 2009) depends on a promoter polymorphism of the tryptophan-hydroxylase 2 gene (TPH2 -703 G/T), which has an impact on 5-HT synthesis (Invernizzi, 2007); and (3) Stroop interference was correlated with the 5-HT transporter density within the DLPFC measured with $\left[{ }^{11} \mathrm{C}\right] \mathrm{DASB}$ positron emission tomography (PET; Madsen et al, 2011). Based on the present findings, we speculate that deficits in conflict monitoring and response inhibition in schizophrenia might be caused by changes in $5-\mathrm{HT}_{2 \mathrm{~A}} \mathrm{R}$ - an assumption that

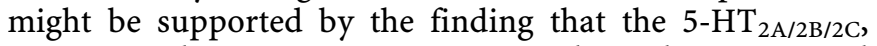
$5-\mathrm{HT}_{1 \mathrm{~A}}$, and $5-\mathrm{HT}_{7} \mathrm{R}$ antagonist cyproheptadine improved RT in the conflict condition of the Stroop Test in chronic schizophrenia patients (Chaudhry et al, 2002), whereas the partial $5-\mathrm{HT}_{1 \mathrm{~A}} \mathrm{R}$ agonist buspirone had no effect on Stroop performance in a comparable patient population (Piskulic et al, 2009).

Given that ketanserin blocks not only the $5-\mathrm{HT}_{2 \mathrm{~A}}$ but also to a lesser extend the $5-\mathrm{HT}_{2 \mathrm{C}} \mathrm{R}$, one might speculate that the $5-\mathrm{HT}_{2 \mathrm{C}} \mathrm{R}$ might also be involved the psilocybin-induced impairments of PPI and Stroop performance seen in this study. An involvement of $5-\mathrm{HT}_{2 \mathrm{C}} \mathrm{R}$ in the effects of hallucinogens has recently proposed based on the observation that $5-\mathrm{HT}_{2 \mathrm{C}} \mathrm{R}$ knock-out mice display a $50 \%$ reduction of DOI-induced head-twitch response - a proposed animal model of human hallucinosis (Canal et al, 2010). However, the psilocin-induced impairments of automatic and controlled inhibition reported here is unlikely to be caused by 5- $\mathrm{HT}_{2 \mathrm{C}} \mathrm{R}$ agonism for several reasons: (1) the selective 5$\mathrm{HT}_{2 \mathrm{C}} \mathrm{R}$ agonist WAY-163909 reverses MK-801- and DOIinduced PPI deficits and does not change or rather increase PPI when given alone (Grauer et al, 2009; Marquis et al, 2007), (2) the selective $5-\mathrm{HT}_{2 \mathrm{C}} \mathrm{R}$ antagonist SDZ SER-082 does not block DOI-induced PPI deficits (Sipes and Geyer, $1995 \mathrm{~b}$ ), and (3) $5-\mathrm{HT}_{2 \mathrm{C}} \mathrm{R}$ agonists enhance while $5-\mathrm{HT}_{2 \mathrm{C}} \mathrm{R}$ antagonists impair behavioral inhibition in rodents (Fletcher et al, 2007; Navarra et al, 2008; Robinson et al, 2008; Winstanley et al, 2004).

In contrast to a previous study, we did not find a significant correlation between Stroop Test performance and PPI (Scholes and Martin-Iverson, 2009). However, Scholes and Martin-Iverson used an attentional modulation 
gating paradigm and calculated PPI by an uncommon technique (non-linear regression fit of mean peak response), which might be not comparable with our approach. Earlier studies employing similar PPI techniques as in the present study also did not find associations between PPI and Stroop Test performance (Swerdlow et al, 1995a,b). Thus, although PPI and Stroop interference are obviously modulated by similar $5-\mathrm{HT}_{2 \mathrm{~A}} \mathrm{R}$ mechanisms, the inhibitory processes engaged in each of the tasks might tap into different regional $5-\mathrm{HT}_{2 \mathrm{~A}} \mathrm{R}$ populations. Animal research has shown that a DOI application in the ventral pallidum disrupts PPI and that this effect was blocked by highly selective $5-\mathrm{HT}_{2 \mathrm{~A}} \mathrm{R}$ antagonists (Sipes and Geyer, 1997). Thus, psilocybin-induced PPI deficits at short ISIs may depend primarily on $5-\mathrm{HT}_{2 \mathrm{~A}} \mathrm{R}$ stimulation located in more basic modulatory structures of the startle circuit such as the striatum or the thalamus (Vollenweider et al, 2007). In contrast, Stroop interference depends on activation of the ACC and DLPFC (Carter et al, 1998; Cohen et al, 2000; Pardo et al, 1990). These regions display a high density of 5- $\mathrm{HT}_{2 \mathrm{~A}} \mathrm{R}$ (Adams et al, 2004; Forutan et al, 2002; Pazos et al, 1987), and $\left[{ }^{18} \mathrm{~F}\right]$ fluorodeoxyglucose PET studies revealed that psilocybin strongly increases regional glucose metabolism in these areas during resting state, especially in the ACC (Gouzoulis-Mayfrank et al, 1999; Vollenweider et al, 1997). Finally, preliminary data from our lab have shown that $5-\mathrm{HT}_{2 \mathrm{~A}} \mathrm{R}$ occupation in the ACC and $\mathrm{MPFC}$ measured with $\left[{ }^{18} \mathrm{~F}\right]$ altanserin PET was correlated with the intensity of the hallucinogenic action of psilocybin (Hasler et al, 2009; Quednow et al, 2010). Thus, although PPIdisrupting effects of psilocybin might be mediated rather by striatal $5-\mathrm{HT}_{2 \mathrm{~A}} \mathrm{R}$, the effect on Stroop interference might be explained by overstimulation of $5-\mathrm{HT}_{2 \mathrm{~A}} \mathrm{R}$ in the prefrontal cortex and the ACC. $5-\mathrm{HT}_{2 \mathrm{~A}} \mathrm{R}$ changes in different brain areas might therefore contribute to diverse alterations in several stages of information processing found in schizophrenia.

To our knowledge, this is the first study investigating the automatic and controlled inhibition processes as well as the psychopathological symptoms via challenge with a hallucinogenic drug in healthy human volunteers. The present study suggests that a stimulation of $5-\mathrm{HT}_{2 \mathrm{~A}} \mathrm{R}$ disrupts sensorimotor gating and Stroop interference, and that these processes likely depend on different regional $5-\mathrm{HT}_{2 \mathrm{~A}} \mathrm{R}$ populations. We therefore propose that $5-\mathrm{HT}_{2 \mathrm{~A}} \mathrm{R}$ changes in cortical and subcortical brain regions might contribute to varied inhibitory deficits of schizophrenia patients.

\section{ACKNOWLEDGEMENTS}

We thank Daniel Bächle and Thomas Joder for technical support. This investigation was financially supported by the Heffter Research Institute, Santa Fe, New Mexico, USA and the Swiss Neuromatrix Foundation. Furthermore, Dr Boris B Quednow was supported by the Deutsche Forschungsgemeinschaft (DFG, Grant QU 218/1-1) and by the Swiss National Science Foundation (Grant No. PP00P1_123516). Dr Mark A. Geyer was supported by the US Veterans Affairs VISN 22 Mental Illness Research, Education and Clinical Center, and holds an equity interest in San Diego
Instruments. Michael Kometer was supported by the Swiss Neuromatrix Foundation. Receptor binding profiles were provided by the National Institute of Mental Health's Psychoactive Drug Screening Program (NIMH PDSP), Contract \# HHSN-271-2008-00025-C The NIMH PDSP is directed by Dr Bryan L. Roth at the University of North Carolina at Chapel Hill and Project Officer Jamie Driscol at NIMH, Bethesda, MD, USA.

\section{DISCLOSURE}

The authors declare no conflict of interest.

\section{REFERENCES}

Adams KH, Pinborg LH, Svarer C, Hasselbalch SG, Holm S, Haugbol S et al (2004). A database of [(18)F]-altanserin binding to $5-\mathrm{HT}(2 \mathrm{~A})$ receptors in normal volunteers: normative data and relationship to physiological and demographic variables. Neuroimage 21: 1105-1113.

Andrews TM, Anderson IM (1998). Information processing in anxiety: a pilot study of the effect of manipulating 5-HT function. J Psychopharmacol 12: 155-160.

Araneda R, Andrade R (1991). 5-Hydroxytryptamine2 and 5-hydroxytryptamine $1 \mathrm{~A}$ receptors mediate opposing responses on membrane excitability in rat association cortex. Neuroscience 40: $399-412$.

Barch DM, Braver TS, Carter CS, Poldrack RA, Robbins TW (2009). CNTRICS final task selection: executive control. Schizophr Bull 35: 115-135.

Blair JB, Kurrasch-Orbaugh D, Marona-Lewicka D, Cumbay MG, Watts VJ, Barker EL et al (2000). Effect of ring fluorination on the pharmacology of hallucinogenic tryptamines. J Med Chem 43: 4701-4710.

Botvinick MM, Cohen JD, Carter CS (2004). Conflict monitoring and anterior cingulate cortex: an update. Trends Cogn Sci 8: 539-546.

Braff D, Stone C, Callaway E, Geyer M, Glick I, Bali L (1978). Prestimulus effects on human startle reflex in normals and schizophrenics. Psychophysiology 15: 339-343.

Braff DL, Geyer MA, Swerdlow NR (2001). Human studies of prepulse inhibition of startle: normal subjects, patient groups, and pharmacological studies. Psychopharmacology (Berl) 156: 234-258.

Braff DL, Grillon C, Geyer MA (1992). Gating and habituation of the startle reflex in schizophrenic patients. Arch Gen Psychiatry 49: 206-215.

Brauer D, Strobel A, Hensch T, Diers K, Lesch KP, Brocke B (2009). Genetic variation of serotonin receptor function affects prepulse inhibition of the startle. J Neural Transm 116: 607-613.

Canal CE, Olaghere da Silva UB, Gresch PJ, Watt EE, Sanders-Bush E, Airey DC (2010). The serotonin 2C receptor potently modulates the head-twitch response in mice induced by a phenethylamine hallucinogen. Psychopharmacology (Berl) 209: 163-174.

Carli M, Baviera M, Invernizzi RW, Balducci C (2006). Dissociable contribution of 5-HT1A and 5-HT2A receptors in the medial prefrontal cortex to different aspects of executive control such as impulsivity and compulsive perseveration in rats. Neuropsychopharmacology 31: 757-767.

Carter CS, Braver TS, Barch DM, Botvinick MM, Noll D, Cohen JD (1998). Anterior cingulate cortex, error detection, and the online monitoring of performance. Science 280: 747-749.

Carter CS, Krener P, Chaderjian M, Northcutt C, Wolfe V (1995). Abnormal Processing of irrelevant information in attentiondeficit hyperactivity disorder. Psychiatry Res 56: 59-70. 
Carter OL, Burr DC, Pettigrew JD, Wallis GM, Hasler F, Vollenweider FX (2005). Using psilocybin to investigate the relationship between attention, working memory, and the serotonin 1A and 2A receptors. J Cogn Neurosci 17: 1497-1508.

Carter OL, Hasler F, Pettigrew JD, Wallis GM, Liu GB, Vollenweider FX (2007). Psilocybin links binocular rivalry switch rate to attention and subjective arousal levels in humans. Psychopharmacology (Berl) 195: 415-424.

Chaudhry IB, Soni SD, Hellewell JS, Deakin JF (2002). Effects of the $5 \mathrm{HT}$ antagonist cyproheptadine on neuropsychological function in chronic schizophrenia. Schizophr Res 53: 17-24.

Cohen JD, Botvinick M, Carter CS (2000). Anterior cingulate and prefrontal cortex: who's in control? Nat Neurosci 3: 421-423.

Cools R, Roberts AC, Robbins TW (2008). Serotoninergic regulation of emotional and behavioural control processes. Trends Cogn Sci 12: 31-40.

Csomor PA, Yee BK, Vollenweider FX, Feldon J, Nicolet T, Quednow BB (2008). On the influence of baseline startle reactivity on the indexation of prepulse inhibition. Behav Neurosci 122: 885-900.

Daumann J, Heekeren K, Neukirch A, Thiel CM, MollerHartmann W, Gouzoulis-Mayfrank E (2008). Pharmacological modulation of the neural basis underlying inhibition of return (IOR) in the human 5-HT2A agonist and NMDA antagonist model of psychosis. Psychopharmacology (Berl) 200: 573-583.

Dean B (2003). The cortical serotonin2A receptor and the pathology of schizophrenia: a likely accomplice. J Neurochem 85: $1-13$.

Derogatis LR (1994). SCL-90-R: Symptom Checklist-90-R: Administration, Scoring and Procedures Manual. National Computer Systems: Minneapolis, MN, USA.

Dittrich A (1994). Psychological aspects of altered states of consciousness of the LSD type: measurements of their basic dimensions and prediction of individual differences. In: Pletscher A, Ladewig D (eds). 50 Years of LSD. Current Status and Perspectives of Hallucinogens. Parthenon Publishing: New York, pp 101-118.

Dittrich A (1998). The standardized psychometric assessment of altered states of consciousness (ASCs) in humans. Pharmacopsychiatry 31: 80-84.

Dittrich A, von Arx S, Staub S (1985). International study on altered states of consciousness (ISASC). Summary of the results. Germ J Psych 9: 319-339.

Evers EA, van der Veen FM, Jolles J, Deutz NE, Schmitt JA (2006). Acute tryptophan depletion improves performance and modulates the BOLD response during a Stroop task in healthy females. Neuroimage 32: 248-255.

Fahrenberg J, Hampel R, Selg H (1984). Das Freiburger Persönlichkeitsinventar FPI. Hogrefe: Göttingen.

Fletcher PJ, Tampakeras M, Sinyard J, Higgins GA (2007). Opposing effects of 5-HT(2A) and 5-HT(2C) receptor antagonists in the rat and mouse on premature responding in the fivechoice serial reaction time test. Psychopharmacology (Berl) 195: 223-234.

Forutan F, Estalji S, Beu M, Nikolaus S, Hamacher K, Coenen HH et al (2002). Distribution of 5HT2A receptors in the human brain: comparison of data in vivo and post mortem. Nuklearmedizin 41: 197-201.

Gallagher P, Massey AE, Young AH, McAllister-Williams RH (2003). Effects of acute tryptophan depletion on executive function in healthy male volunteers. BMC Psychiatry 3: 10.

Geyer MA, Braff DL (1987). Startle habituation and sensorimotor gating in schizophrenia and related animal models. Schizophr Bull 13: 643-668.

Geyer MA, Vollenweider FX (2008). Serotonin research: contributions to understanding psychoses. Trends Pharmacol Sci 29: $445-453$
Gogos A, Nathan PJ, Guille V, Croft RJ, van den Buuse M (2006). Estrogen prevents 5-HT1A receptor-induced disruptions of prepulse inhibition in healthy women. Neuropsychopharmacology 31: 885-889.

Gouzoulis-Mayfrank E, Arnold S, Heekeren K (2006a). Deficient inhibition of return in schizophrenia-further evidence from an independent sample. Prog Neuropsychopharmacol Biol Psychiatry 30: 42-49.

Gouzoulis-Mayfrank E, Balke M, Hajsamou S, Ruhrmann S, Schultze-Lutter F, Daumann J et al (2007). Orienting of attention in unmedicated patients with schizophrenia, prodromal subjects and healthy relatives. Schizophr Res 97: 35-42.

Gouzoulis-Mayfrank E, Heekeren K, Neukirch A, Stoll M, Stock C, Daumann J et al (2006b). Inhibition of return in the human 5HT2A agonist and NMDA antagonist model of psychosis. Neuropsychopharmacology 31: 431-441.

Gouzoulis-Mayfrank E, Heekeren K, Thelen B, Lindenblatt H, Kovar KA, Sass H et al (1998). Effects of the hallucinogen psilocybin on habituation and prepulse inhibition of the startle reflex in humans. Behav Pharmacol 9: 561-566.

Gouzoulis-Mayfrank E, Heekeren K, Voss T, Moerth D, Thelen B, Meincke U (2004). Blunted inhibition of return in schizophrenia-evidence from a longitudinal study. Prog Neuropsychopharmacol Biol Psychiatry 28: 389-396.

Gouzoulis-Mayfrank E, Schreckenberger M, Sabri O, Arning C, Thelen B, Spitzer M et al (1999). Neurometabolic effects of psilocybin, 3,4-methylenedioxyethylamphetamine (MDE) and dmethamphetamine in healthy volunteers. A double-blind, placebo-controlled PET study with [18F]FDG. Neuropsychopharmacology 20: 565-581.

Gouzoulis-Mayfrank E, Thelen B, Maier S, Heekeren K, Kovar KA, Sass $\mathrm{H}$ et al (2002). Effects of the hallucinogen psilocybin on covert orienting of visual attention in humans. Neuropsychobiology 45: 205-212.

Graham FK (1975). The more or less startling effects of weak prestimulation. Psychophysiology 12: 238-248.

Graham SJ, Langley RW, Balboa VA, Bradshaw CM, Szabadi E (2002). Effects of ketanserin and haloperidol on prepulse inhibition of the acoustic startle (eyeblink) response and the N1/P2 auditory evoked response in man. J Psychopharmacol 16: $15-22$.

Grauer SM, Graf R, Navarra R, Sung A, Logue SF, Stack G et al (2009). WAY-163909, a 5-HT2C agonist, enhances the preclinical potency of current antipsychotics. Psychopharmacology (Berl) 204: $37-48$.

Halberstadt AL, Geyer MA (2010). LSD but not lisuride disrupts prepulse inhibition in rats by activating the $5-\mathrm{HT}(2 \mathrm{~A})$ receptor. Psychopharmacology (Berl) 208: 179-189.

Hasler F, Bourquin D, Brenneisen R, Bar T, Vollenweider FX (1997). Determination of psilocin and 4-hydroxyindole-3-acetic acid in plasma by HPLC-ECD and pharmacokinetic profiles of oral and intravenous psilocybin in man. Pharm Acta Helv 72: 175-184.

Hasler F, Bourquin D, Brenneisen R, Vollenweider FX (2002). Renal excretion profiles of psilocin following oral administration of psilocybin: a controlled study in man. J Pharm Biomed Anal 30: $331-339$.

Hasler F, Quednow BB, Treyer V, Schubiger PA, Buck A, Vollenweider FX (2009). Role of prefrontal serotonin-2A receptors in self-experience during psilocybin-induced altered states. Neuropsychobiology 59: S60.

Henik A, Salo R (2004). Schizophrenia and the stroop effect. Behav Cogn Neurosci Rev 3: 42-59.

Horacek J, Zavesicka L, Tintera J, Dockery C, Platilova V, Kopecek M et al (2005). The effect of tryptophan depletion on brain activation measured by functional magnetic resonance imaging during the Stroop test in healthy subjects. Physiol Res 54: $235-244$ 
Invernizzi RW (2007). Role of TPH-2 in brain function: news from behavioral and pharmacologic studies. J Neurosci Res 85: 3030-3035.

Jensen KS, Oranje B, Wienberg M, Glenthoj BY (2007). The effects of increased central serotonergic activity on prepulse inhibition and habituation of the human startle response. Neuropsychopharmacology 32: 2117-2124.

Johansson C, Jackson DM, Zhang J, Svensson L (1995). Prepulse inhibition of acoustic startle, a measure of sensorimotor gating: effects of antipsychotics and other agents in rats. Pharmacol Biochem Behav 52: 649-654.

Kometer M, Cahn BR, Andel D, Carter OL, Vollenweider FX (2011). The 5-HT2A/1A agonist psilocybin disrupts modal object completion associated with visual hallucinations. Biol Psychiatry 69: 399-406.

Krebs-Thomson K, Ruiz EM, Masten V, Buell M, Geyer MA (2006). The roles of 5-HT1A and 5-HT2 receptors in the effects of 5$\mathrm{MeO}-\mathrm{DMT}$ on locomotor activity and prepulse inhibition in rats. Psychopharmacology (Berl) 189: 319-329.

Krus DM, Wapner S, Freeman H, Casey TM (1963). Differential behavioral responsivity to LSD-25, study in normal and schizophrenic adults. Arch Gen Psychiatry 8: 557-563.

Kumari V, Gray JA (1999). Smoking withdrawal, nicotine dependence and prepulse inhibition of the acoustic startle reflex. Psychopharmacology (Berl) 141: 11-15.

Kumari V, Soni W, Mathew VM, Sharma T (2000). Prepulse inhibition of the startle response in men with schizophrenia: effects of age of onset of illness, symptoms, and medication. Arch Gen Psychiatry 57: 609-614.

Ludewig K, Geyer MA, Vollenweider FX (2003). Deficits in prepulse inhibition and habituation in never-medicated, firstepisode schizophrenia. Biol Psychiatry 54: 121-128.

MacLeod CM (1991). Half a century of research on the Stroop effect: an integrative review. Psychol Bull 109: 163-203.

Madsen K, Erritzoe D, Mortensen EL, Gade A, Madsen J, Baare W et al (2011). Cognitive function is related to fronto-striatal serotonin transporter levels-a brain PET study in young healthy subjects. Psychopharmacology (Berl) 213: $573-581$.

Mansouri FA, Tanaka K, Buckley MJ (2009). Conflict-induced behavioural adjustment: a clue to the executive functions of the prefrontal cortex. Nat Rev Neurosci 10: 141-152.

Marquis KL, Sabb AL, Logue SF, Brennan JA, Piesla MJ, Comery TA et al (2007). WAY-163909 [(7bR,10aR)-1,2,3,4,8,9,10,10aoctahydro-7bH-cyclopenta-[b][1,4]diazepino[6,7,1hi]indole]: A novel 5-hydroxytryptamine $2 \mathrm{C}$ receptor-selective agonist with preclinical antipsychotic-like activity. J Pharmacol Exp Ther 320: 486-496.

Martin-Ruiz R, Ugedo L, Honrubia MA, Mengod G, Artigas F (2001). Control of serotonergic neurons in rat brain by dopaminergic receptors outside the dorsal raphe nucleus. J Neurochem 77: 762-775.

McGhie A, Chapman J (1961). Disorders of attention and perception in early schizophrenia. $\mathrm{Br} J$ Med Psychol 34: 103-116.

Melcher T, Falkai P, Gruber O (2008). Functional brain abnormalities in psychiatric disorders: neural mechanisms to detect and resolve cognitive conflict and interference. Brain Res Rev 59: 96-124.

Meltzer HY (1999). The role of serotonin in antipsychotic drug action. Neuropsychopharmacology 21: 106S-115S.

Meltzer HY, Li Z, Kaneda Y, Ichikawa J (2003). Serotonin receptors: their key role in drugs to treat schizophrenia. Prog Neuropsychopharmacol Biol Psychiatry 27: 1159-1172.

Navarra R, Comery TA, Graf R, Rosenzweig-Lipson S, Day M (2008). The 5-HT(2C) receptor agonist WAY-163909 decreases impulsivity in the 5-choice serial reaction time test. Behav Brain Res 188: 412-415.
Nuechterlein KH, Dawson ME (1984). Information processing and attentional functioning in the developmental course of schizophrenic disorders. Schizophr Bull 10: 160-203.

Nuechterlein KH, Dawson ME, Green MF (1994). Informationprocessing abnormalities as neuropsychological vulnerability indicators for schizophrenia. Acta Psychiatr Scand Suppl 384: 71-79.

Oranje B, Wienberg M, Glenthoj BY (2011). A single high dose of escitalopram disrupts sensory gating and habituation, but not sensorimotor gating in healthy volunteers. Psychiatry Res 186: 431-436.

Osinsky R, Schmitz A, Alexander N, Kuepper Y, Kozyra E, Hennig J (2009). TPH2 gene variation and conflict processing in a cognitive and an emotional Stroop task. Behav Brain Res 198: 404-410.

Ouagazzal AM, Grottick AJ, Moreau JL, Higgins GA (2001). Effect of LSD on prepulse inhibition and spontaneous behavior in the rat: A pharmacological analysis and comparison between two rat strains. Neuropsychopharmacology 25: 565-575.

Padich RA, McCloskey TC, Kehne JH (1996). 5-HT modulation of auditory and visual sensorimotor gating.2. Effects of the 5-HT2A antagonist MDL 100,907 on disruption of sound and light prepulse inhibition produced by 5 -HT agonists in Wistar rats. Psychopharmacology 124: 107-116.

Pardo JV, Pardo PJ, Janer KW, Raichle ME (1990). The anterior cingulate cortex mediates processing selection in the Stroop attentional conflict paradigm. Proc Natl Acad Sci USA 87: 256-259.

Parwani A, Duncan EJ, Bartlett E, Madonick SH, Efferen TR, Rajan $\mathrm{R}$ et al (2000). Impaired prepulse inhibition of acoustic startle in schizophrenia. Biol Psychiatry 47: 662-669.

Passie T, Seifert J, Schneider U, Emrich HM (2002). The pharmacology of psilocybin. Addict Biol 7: 357-364.

Pazos A, Probst A, Palacios JM (1987). Serotonin receptors in the human brain-IV. Autoradiographic mapping of serotonin-2 receptors. Neuroscience 21: 123-139.

Persson B, Pettersson A, Hedner T (1987). Pharmacokinetics of ketanserin in patients with essential hypertension. Eur J Clin Pharmacol 32: 259-265.

Piskulic D, Olver JS, Maruff P, Norman TR (2009). Treatment of cognitive dysfunction in chronic schizophrenia by augmentation of atypical antipsychotics with buspirone, a partial 5-HT(1A) receptor agonist. Hum Psychopharmacol 24: 437-446.

Quednow BB, Frommann I, Berning J, Kuhn KU, Maier W, Wagner M (2008a). Impaired sensorimotor gating of the acoustic startle response in the prodrome of schizophrenia. Biol Psychiatry 64: 766-773.

Quednow BB, Geyer MA, Halberstadt AL (2010). Serotonin and schizophrenia. In: Müller CP, Jacobs BL (eds). Handbook of the Behavioral Neurobiology of Serotonin. Academic Press: London, Vol 18. pp 585-620.

Quednow BB, Kuhn KU, Mossner R, Schwab SG, Schuhmacher A, Maier W et al (2008b). Sensorimotor gating of schizophrenia patients is influenced by 5-HT2A receptor polymorphisms. Biol Psychiatry 64: 434-437.

Quednow BB, Kuhn KU, Stelzenmuelle R, Hoenig K, Maier W, Wagner M (2004). Effects of serotonergic and noradrenergic antidepressants on auditory startle response in patients with major depression. Psychopharmacology (Berl) 175: 399-406.

Quednow BB, Schmechtig A, Ettinger U, Petrovsky N, Collier DA, Vollenweider FX et al (2009). Sensorimotor gating depends on polymorphisms of the serotonin-2A receptor and catechol-Omethyltransferase, but not on neuregulin-1 Arg38Gln genotype: a replication study. Biol Psychiatry 66: 614-620.

Quednow BB, Wagner M, Westheide J, Beckmann K, Bliesener N, Maier W et al (2006). Sensorimotor gating and habituation of the startle response in schizophrenic patients randomly treated with amisulpride or olanzapine. Biol Psychiatry 59: 536-545. 
Reuter M, Ott U, Vaitl D, Hennig J (2007). Impaired executive control is associated with a variation in the promoter egion of the tryptophan hydroxylase 2 gene. J Cogn Neurosci 19: 401-408.

Robinson ES, Dalley JW, Theobald DE, Glennon JC, Pezze MA, Murphy ER et al (2008). Opposing roles for 5-HT2A and 5HT2C receptors in the nucleus accumbens on inhibitory response control in the 5-choice serial reaction time task. Neuropsychopharmacology 33: 2398-2406.

Sard H, Kumaran G, Morency C, Roth BL, Toth BA, He P et al (2005). SAR of psilocybin analogs: discovery of a selective 5-HT 2C agonist. Bioorg Med Chem Lett 15: 4555-4559.

Schmitt JA, Jorissen BL, Sobczak S, van Boxtel MP, Hogervorst E, Deutz NE et al (2000). Tryptophan depletion impairs memory consolidation but improves focussed attention in healthy young volunteers. J Psychopharmacol 14: 21-29.

Scholes KE, Harrison BJ, O’Neill BV, Leung S, Croft RJ, Pipingas A et al (2007). Acute serotonin and dopamine depletion improves attentional control: findings from the stroop task. Neuropsychopharmacology 32: 1600-1610.

Scholes KE, Martin-Iverson MT (2009). Relationships between prepulse inhibition and cognition are mediated by attentional processes. Behav Brain Res 205: 456-467.

Sipes TA, Geyer MA (1995a). 8-OH-DPAT disruption of prepulse inhibition in rats: reversal with $(+)$ WAY 100,135 and localization of site of action. Psychopharmacology (Berl) 117: 41-48.

Sipes TE, Geyer MA (1995b). DOI disruption of prepulse inhibition of startle in the rat is mediated by $5-\mathrm{HT}(2 \mathrm{~A})$ and not by 5-HT(2C) receptors. Behav Pharmacol 6: 839-842.

Sipes TE, Geyer MA (1997). DOI disrupts prepulse inhibition of startle in rats via 5-HT2A receptors in the ventral pallidum. Brain Res 761: 97-104.

Sobczak S, Riedel WJ, Booij I, Aan Het Rot M, Deutz NE, Honig A (2002). Cognition following acute tryptophan depletion: difference between first-degree relatives of bipolar disorder patients and matched healthy control volunteers. Psychol Med 32: $503-515$.

Soubrié P (1986). Reconciling the role of central serotonin neurones in human and animal behavior. Behav Brain Res 9: 319-364.

Spielberger CD, Gorsuch RL, Lusheme RE (1970). STAI, Manual for the State-Trait-Anxiety-Inventory. Consulting Psychologists Press: Palo Alto.

Spreen O, Strauss E (1998). A Compendium of Neuropsychological Tests: Administration, Norms, and Commentary, 2. edn. Oxford University Press: Oxford.

Studerus E, Kometer M, Hasler F, Vollenweider FX (2011). Acute, subacute and long-term subjective effects of psilocybin in healthy humans: a pooled analysis of experimental studies. $J$ Psychopharmacol (in press).

Swerdlow NR, Filion D, Geyer MA, Braff DL (1995a). 'Normal personality' correlates of sensorimotor, cognitive, and visuospatial gating. Biol Psychiatry 37: 286-299.
Swerdlow NR, Hartman PL, Auerbach PP (1997). Changes in sensorimotor inhibition across the menstrual cycle: Implications for neuropsychiatric disorders. Biol Psychiatry 41: 452-460.

Swerdlow NR, Light GA, Cadenhead KS, Sprock J, Hsieh MH, Braff DL (2006). Startle gating deficits in a large cohort of patients with schizophrenia: relationship to medications, symptoms, neurocognition, and level of function. Arch Gen Psychiatry 63: $1325-1335$.

Swerdlow NR, Paulsen J, Braff DL, Butters N, Geyer MA, Swenson MR (1995b). Impaired prepulse inhibition of acoustic and tactile startle response in patients with Huntington's disease. J Neurol Neurosurg Psychiatry 58: 192-200.

van den Buuse M, Gogos A (2007). Differential effects of antipsychotic drugs on serotonin-1A receptor-mediated disruption of prepulse inhibition. J Pharmacol Exp Ther 320: 1224-1236.

Venables PH (1960). The effect of auditory and visual stimulation on the skin potential response of schizophrenics. Brain 83: 77-92.

Vollenweider FX, Csomor PA, Knappe B, Geyer MA, Quednow BB (2007). The effects of the preferential 5-HT2A agonist psilocybin on prepulse inhibition of startle in healthy human volunteers depend on interstimulus interval. Neuropsychopharmacology 32: 1876-1887.

Vollenweider FX, Gamma AG, Liechti M, Huber T (1998a). Psychological and cardiovascular effects and short-term sequelae of MDMA ('Ecstasy') in MDMA-naive healthy volunteers. Neuropsychopharmacology 19: 241-251.

Vollenweider FX, Leenders KL, Scharfetter C, Maguire P, Stadelmann O, Angst J (1997). Positron emission tomography and fluorodeoxyglucose studies of metabolic hyperfrontality and psychopathology in the psilocybin model of psychosis. Neuropsychopharmacology 16: 357-372.

Vollenweider FX, Remensberger S, Hell D, Geyer MA (1999). Opposite effects of 3,4-methylenedioxymethamphetamine (MDMA) on sensorimotor gating in rats versus healthy humans. Psychopharmacology 143: 365-372.

Vollenweider FX, Vollenweider-Scherpenhuyzen MF, Babler A, Vogel H, Hell D (1998b). Psilocybin induces schizophrenia-like psychosis in humans via a serotonin-2 agonist action. Neuroreport 9: 3897-3902.

Wapner S, Krus DM (1960). Effects of lysergic acid diethylamide, and differences between normals and schizophrenics on the Stroop Color-Word Test. J Neuropsychiatr 2: 76-81.

Winstanley CA, Theobald DE, Dalley JW, Glennon JC, Robbins TW (2004). 5-HT2A and 5-HT2C receptor antagonists have opposing effects on a measure of impulsivity: interactions with global 5-HT depletion. Psychopharmacology (Berl) 176: 376-385.

Wittchen HU, Pfister H (1997). DIA-X-Interview. Swets Test Service: Frankfurt.

Wittmann M, Carter O, Hasler F, Cahn BR, Grimberg U, Spring P et al (2007). Effects of psilocybin on time perception and temporal control of behaviour in humans. J Psychopharmacol 21: $50-64$. 